\title{
Recircumscription of Begonia sect. Baryandra (Begoniaceae): evidence from molecular data
}

\author{
Rosario Rivera Rubite ${ }^{1}$, Mark Hughes ${ }^{2^{*}}$, Grecebio JD Alejandro ${ }^{3}$ and Ching-I Peng ${ }^{4^{*}}$
}

\begin{abstract}
Background: Begonia sect. Diploclinium is a 'dust-bin' section for species retaining pleisiomorphic characters and lacking novel synapomorphic characters used to delimit other Asian sections in Begonia. Part of this large and polymorphous section is transferred to Begonia sect. Baryandra in a move towards a more natural classification for the genus.

Results: Phylogenetic analysis of nuclear ribosomal ITS DNA sequences show a strongly supported monophyletic group containing Philippine and Bornean species previously in Begonia sect. Diploclinium, and the type of Begonia sect. Baryandra, B. oxysperma. This clade forms the basis for the now much-expanded Begonia sect. Baryandra, which as defined here contains 49 species and has its centre of diversity in the Philippines.

Conclusions: A natural classification for a much expanded Begonia sect. Baryandra has been provided. This paper highlights the feasibility of moving towards a natural classification of Asian Begonia step by step as information comes to light through building upon previous framework phylogenies with denser sampling.
\end{abstract}

Keywords: Begonia; Classification; Section; Phylogeny; Taxonomy

\section{Background}

Large genera are unwieldy units that make aspects of their biogeography, ecology or morphology difficult to discuss without dividing them into smaller groupings. In large genera, infrageneric ranks take over the function of the genus as it is used for less species-rich groups; subgenera or sections are able to divide large genera into more manageable units for discussing and communicating biological information. Ideally, sub-generic taxa will have a biological reality, e.g. be monophyletic, to make them meaningful, as opposed to being groupings of phenetically similar but possibly not closely related species. Sub-generic taxa have another use in that they allow one to freely move species from one higher taxon to another without having to formally publish new combinations and leaving an untidy nomenclatural trail. This is particularly relevant for using the rank of section in Begonia. Following the reduction of the many genera formerly recognised by Klotzsch (1855), the delimitation of the genus Begonia is currently uncontroversial,

\footnotetext{
*Correspondence: m.hughes@rbge.ac.uk; bopeng@sinica.edu.tw

${ }^{2}$ Royal Botanic Garden Edinburgh, 20a Inverleith Row, Edinburgh EH3 5LR, UK

${ }^{4}$ Biodiversity Research Center, Academia Sinica, Taipei 115, Taiwan

Full list of author information is available at the end of the article
}

however there is still a lot of uncertainty about which sections some species belong to (Doorenbos et al., 1998). Although much work remains to be done in terms of understanding the relationships of the ca. 1600 species of Begonia, enough phylogenetic evidence is available (Forrest et al., 2005; Tebbitt, 2006; Thomas et al., 2011; this study) to enable us to start making some changes in sectional delimitation. This means we can begin to move away from a classification based on making-do with sections which in some cases are not only polyphyletic, but also scarcely phenetically similar assemblages such as Begonia sect. Diploclinium (Doorenbos et al., 1998; Thomas et al., 2011).

Begonia sect. Diploclinium is one of the most problematic sections in the genus, Doorenbos et al., (1998) referred to it as "a show-case of the difficulties one meets when trying to delimit sections". The lack of distinguishing characters for the section has been highlighted by Shui et al., (2002) who note its similarity to not only other Asian sections but also the New World Begonia sect. Begonia and Begonia sect. Knesebeckia. Based on an analysis of how morphological characters used in defining Begonia sections evolve across a chloroplast DNA phylogeny (Thomas et al., 2011), it has become clear that Begonia sect. Diploclinium is a 'dust-bin'

\section{实}


section for species retaining pleisiomorphic characters and lacking novel synapomorphic characters used to delimit other Asian sections. The same study shows that its type species, Begonia grandis, diverges at the base of a grade of tuberous species from continental Asia; nested within this grade are Begonia sect. Sphenanthera and Begonia sect. Platycentrum. Philippine species assigned to Begonia sect. Diploclinium do not fall within this clade, but are nested within a predominantly Malesian clade and sister to Begonia sect. Reichenheimea (Tebbitt, 2006; Thomas et al., 2011). The placement of the Philippine species in Begonia sect. Diploclinium is based solely on the presence of bifid placentae, a character found in the majority of the species of Begonia (Forrest et al., 2005). Following a review of morphology (Rubite, 2012) and additional phylogenetic investigations with increased taxon sampling (Figure 1), we here formally move a group of largely Philippine species previously in Begonia sect. Diploclinium into a much expanded Begonia sect. Baryandra, previously containing only Begonia oxysperma.

\section{Methods}

DNA sequences of the nuclear ribosomal internal transcribed spacers ITS1 and ITS2 plus the 5.8S gene were obtained from samples of Begonia sect. Coelocentrum, Begonia sect. Leprosae (outgroups), Begonia sect.
Ridleyella, Begonia sect. Reichenheimea and 21 out of 49 species in Begonia sect. Baryandra as recircumscribed here using the methods of Forrest et al., (2005) (Table 1). Considering both morphological (Doorenbos et al., 1998) and molecular (Tebbitt et al., 2006; Thomas et al., 2011) data the closest relatives of the Philippine species in Begonia sect. Baryandra are species in Begonia sect. Reichenheimea from the Sunda Shelf. The sampling was designed to test the monophyly of these two sections. In addition, morphologically divergent species of Begonia sect. Baryandra were sampled (B. coronensis, which has entire placentae; $B$. anisoptera, $B$. gueritziana and $B$. suborbiculata, which have 2-locular fruit), as was the type of Begonia sect. Baryandra, B. oxysperma. The type of Begonia sect. Diploclinium, B. grandis, was not included as the sequences are too divergent to align unambiguously with the other samples, and previous work (Thomas et al., 2011) has shown that it does not belong to the ingroup. Sequences were aligned manually, and a phylogenetic analysis was carried out using MrBayes (Ronquist et al., 2012) using a GTR + G model of sequence evolution, 10 million generations and a burn-in of $25 \%$.

\section{Results}

The phylogeny obtained (Figure 1) shows a strongly supported monophyletic group containing Philippine and

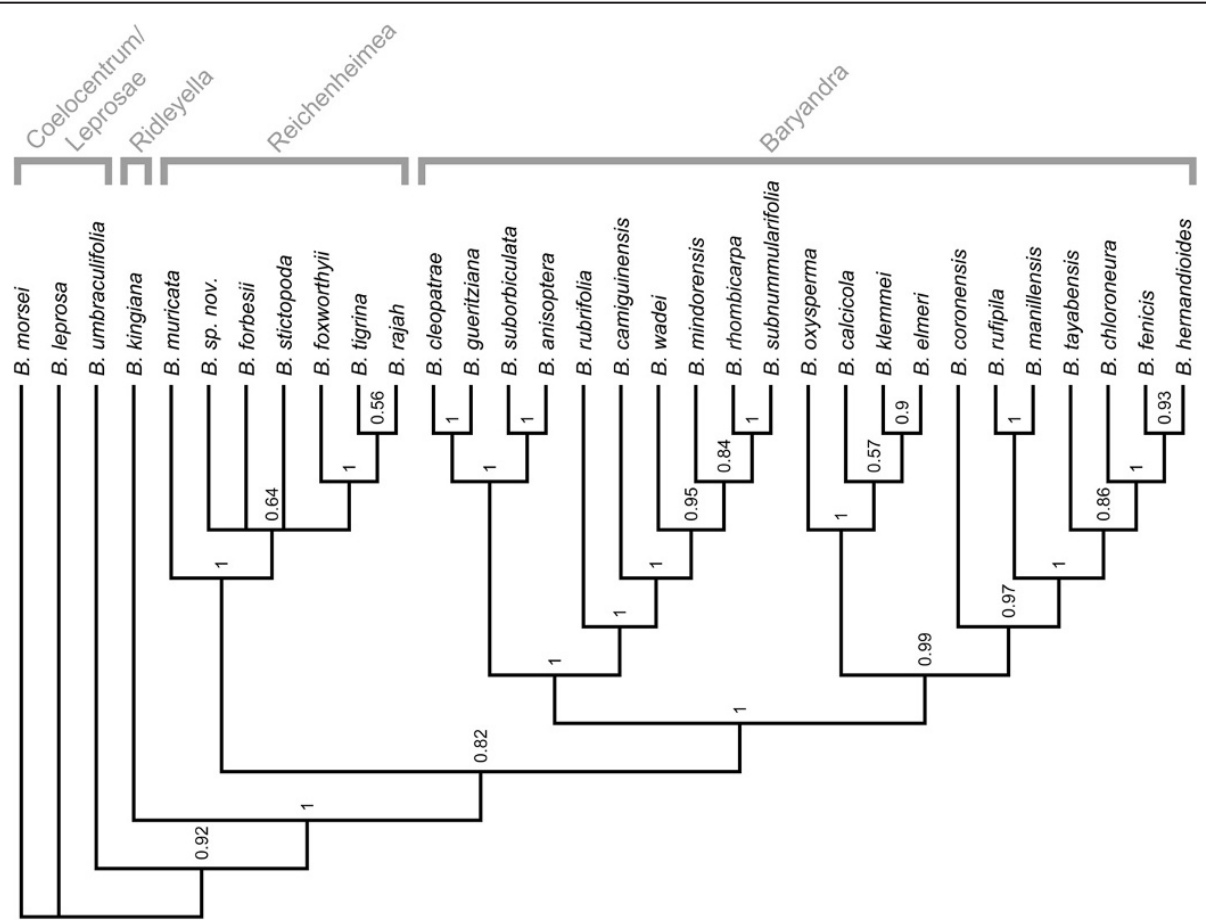

Figure 1 Cladogram of a Bayesian phylogenetic analysis of nuclear ribosomal internal transcribed spacer DNA sequences from Begonia sect. Coelocentrum, Begonia sect. Leprosae (outgroups), Begonia sect. Ridleyella, Begonia sect. Reichenheimea and 21 out of 55 species in Begonia sect. Baryandra. Numbers above the nodes show posterior probability. 


\begin{tabular}{|c|c|c|}
\hline Species & GenBank accession & Voucher \\
\hline B. anisoptera & JX656720 & Rubite R479 (PNH) \\
\hline B. calcicola & JX656708 & Peng P20761 (HAST) \\
\hline B. camiguinensis & JX656721 & Rubite R506 (PNH) \\
\hline B. chloroneura & AF485134 & Forrest $128(\mathrm{E})$ \\
\hline B. cleopatrae & AF485133 & Forrest $127(\mathrm{E})$ \\
\hline B. coronensis & JX656715 & Rubite R323 (PNH) \\
\hline B. elmeri & JX656714 & Rubite R319 (PNH) \\
\hline B. fenicis & JX678218 & Peng P18366 (HAST) \\
\hline B. forbesii & JX656704 & Peng P22685 (HAST) \\
\hline B. foxworthyii & JX656702 & Peng P22721 (HAST) \\
\hline B. gueritziana & JX678217 & Peng 21976 (HAST) \\
\hline B. hernandioides & JX656707 & Rubite R106 (PNH) \\
\hline B. kingiana & AF485139 & Forrest 133 (E) \\
\hline B. klemmei & JX656709 & Rubite R182 (PNH) \\
\hline B. leprosa & AY753722 & Tebbitt 94 (BKL) \\
\hline B. manillensis & $J \times 656713$ & Rubite R304 (PNH) \\
\hline B. mindorensis & JX656717 & Rubite R354 (PNH) \\
\hline B. morsei & AF485130 & No voucher \\
\hline B. muricata & AY753725 & Hoover 901 (A) \\
\hline B. oxysperma & JX656710 & Rubite R213 (PNH) \\
\hline B. rajah & AF485136 & Forrest $130(\mathrm{E})$ \\
\hline B. rhombicarpa & JX656719 & Rubite R419 (PNH) \\
\hline B. rubrifolia & JX656711 & Rubite R234 (PNH) \\
\hline B. rufipila & JX656712 & Rubite R265 (PNH) \\
\hline B. sp. nov. & JX656701 & Girmansyah \& Hughes DEDEN1490 (E) \\
\hline B. stictopoda & JX656705 & Hughes MH1409 (E) \\
\hline B. subnummularifolia & JX656722 & No voucher \\
\hline B. suborbiculata & $J \times 656716$ & Rubite R353 (PNH) \\
\hline B. tayabensis & JX656718 & Rubite R360 (PNH) \\
\hline B. tigrina & JX656703 & Peng P22720 (HAST) \\
\hline B. umbraculifolia & JF976054 & Shui et al., SYM-B2005-086-sample2 (KUN) \\
\hline B. wadei & JX656706 & Rubite 699 (PNH) \\
\hline
\end{tabular}

Bornean species previously in Begonia sect. Diploclinium, and the type of Begonia sect. Baryandra, B. oxysperma. This clade forms the basis for the now much-expanded Begonia sect. Baryandra, which as defined here contains 49 species and has its centre of diversity in the Philippines.

\section{Discussion}

Begonia sect. Baryandra is morphologically most similar to (and phylogenetically closest to) Begonia sect. Reichenheimea as represented by species from Peninsular Malaysia and Sumatra, differing in having 2 placentae per locule (not 1) and boat-shaped, entire, sheathing bracts (not flat-ovate, minutely fimbriate, reflexed bracts). We reviewed the morphology of all Malesian species in Begonia sect. Diploclinium (Hughes, 2008) to determine if they should be placed in Begonia sect. Baryandra, and several were found not to have affinity with sect. Baryandra as delimited here. Begonia longovillosa from the Philippines is known only from a very short protologue and is here considered unplaced to section. From Peninsular Malaysia there are two species of Begonia sect. Diploclinium that do not match sect. Baryandra (Kiew, 2005). Begonia jayaensis has bracts fringed with glandular hairs, with 1 or 25 -tepalled carpellate 
flowers borne at the base of a larger staminate inflorescence and is probably referable to Begonia sect. Petermannia. Begonia lowiana is a caulescent species of uncertain affinity with the rest of Begonia sect. Diploclinium, and not allied to any Philippine taxa. From Sumatra there are three Begonia sect. Diploclinium species recorded; Begonia sublobata Jack has entire placentae and has been transferred to Begonia sect. Reichenheimea (Hughes and Girmansyah, 2011). The other two species, Begonia hasskarliana and B. ionophylla, are poorly known and information on their placentation is lacking; given their geographic location they likely also belong to Begonia sect. Reichenheimea and do not have affinity with Begonia sect. Baryandra.

There are four remaining Bornean species of Begonia sect. Diploclinium that we have not transferred to Begonia sect. Baryandra. Begonia piring has paired carpellate flowers with 5 tepals borne beneath a larger staminate inflorescence and hence is likely affiliated with Begonia sect. Petermannia. Begonia havilandii is known only from the protologue, but the description includes a paniculate inflorescence, carpellate flowers with 6 tepals and toothed bracts with glandular hairs, which are again suggestive of sect. Petermannia with an affinity to other creeping species such as B. humericola Sands. Begonia sabahensis and $B$. calcarea are closely allied species with orange and yellow flowers respectively, borne on separate umbellate staminate and unifloral carpellate inflorescences. The carpellate flowers have 5 tepals, and the staminate flowers have lax sessile stamens; it is not immediately clear which section these belong to, but it is obvious they have no affinity to Begonia sect. Baryandra.

With the exception of Begonia sharpeana, all of the other six species of Begonia sect. Diploclinium from New Guinea differ considerably from Begonia sect. Baryandra in either being tuberous, having a highly reduced number of stamens, lax and sessile androecia, or spurred fruit. These and the other species above which we have not transferred to Begonia sect. Baryandra we leave in Begonia sect. Diploclinium until further molecular or morphological data are known. A full recircumscription of Begonia sect. Diploclinium is beyond the scope of this paper, and will involve enlarging more of the currently described sections of the genus and will likely require several more to be proposed. Much more sampling across Asia is needed before this can be done with confidence, and this is likely to take some time.

\section{Taxonomic treatment}

Begonia sect. Baryandra A.DC. Type species: Begonia oxysperma A.DC.

Herbs, rhizomatous (rarely lianescent: B. oxysperma), lacking an erect stem. Tubers absent. Stipules persistent, entire, ovate to lanceolate apex with a filiform extension, glabrous or hairy, adaxial surface often keeled. Leaves alternate, petiolate; petioles terete, glabrous to densely hairy; lamina usually asymmetric, basifixed or peltate, venation palmatepinnate, abaxially with hairs on the veins, adaxially usually glabrous. Inflorescences axillary, dichasial, bisexual cymes, with staminate flowers basal and carpellate flowers distal, protandrous; bracts boat-shaped, entire, usually sheathing developing buds, caducous. Staminate flowers with 4 free perianth segments; androecium actinomorphic, filaments fused below into a short column, anthers oblong, shorter than the filaments, dehiscing with laterally positioned short slits. Carpellate flowers with 4 (rarely 5: B. chloroneura, $B$. fenicis, B. hernandioides, $B$. tayabensis) perianth segments; ovary with 3 equal or unequal wings, locules $(2$ or) 3 , placentation axillary, placental branches 2 per locule (rarely 1 : B. coronensis), ovules present between placental branches; styles 3, persistent or caducous in fruit, stigma in a spiralled band. Fruit pendulous or recurved at maturity.

BORNEO. Begonia diwolii Kiew, Begonia gueritziana Gibbs, Begonia subnummularifolia Merr.

PHILIPPINES. Begonia acclivis Coyle, Begonia acuminatissima Merr. (synonym: Begonia camiguinensis Elmer), Begonia alba Merr., Begonia alvarezii Merr., Begonia angilogensis Merr., Begonia anisoptera Merr., Begonia biliranensis Merr., Begonia blancii M.Hughes, Begonia calcicola Merr., Begonia castilloi Merr., Begonia chloroneura P.Wilkie \& Sands, Begonia cleopatrae Coyle, Begonia collisiae Merr., Begonia colorata Warb., Begonia copelandii Merr., Begonia coronensis Merr., Begonia elmeri Merr., Begonia fenicis Merr., Begonia gitingensis Elmer, Begonia gutierrezii Coyle, Begonia hernandioides Merr., Begonia isabelensis Quisumb. \& Merr., Begonia klemmei Merr., Begonia lancilimba Merr., Begonia longinoda Merr., Begonia longiscapa Warb., Begonia luzonensis Warb., Begonia manillensis A.DC., Begonia mindorensis Merr. (synonyms: Begonia pinamalayensis Merr., Begonia sordidissima Elmer), Begonia neopurpurea L.B.Sm. \& Wassh., Begonia obtusifolia Merr., Begonia oxysperma A.DC., Begonia parva Merr., Begonia rhombicarpa A.DC. (synonyms: Begonia merrillii Warb., Begonia nigritarum Steud. ex Merr., Begonia rhombicarpa var. lobbii A.DC.), Begonia rubitae M. Hughes, Begonia rubrifolia Merr., Begonia rufipila Merr., Begonia serpens Merr., Begonia suborbiculata Merr., Begonia tayabensis Merr., Begonia trichocheila Warb., Begonia vanoverberghii Merr., Begonia wadei Merr. \& Quisumb., Begonia wilkiei Coyle, Begonia woodii Merr.

NEW GUINEA. Begonia sharpeana F.Muell.

\section{Conclusion}

A natural classification for a much expanded Begonia sect. Baryandra has been provided. A total of 49 species is now considered to belong to the section, which has its centre of diversity in the Philippines but also with some 
representatives in Borneo and New Guinea. This paper highlights the feasibility of moving towards a natural classification of Asian Begonia step by step as information comes to light through building upon previous framework phylogenies with denser sampling.

\section{Competing interests}

The authors declare that they have no competing interests.

\section{Authors' contribution}

$\mathrm{MH}$ carried out the molecular study and drafted the manuscript; RR \& CP participated in sample collection and the taxonomic treatment; RR, CP \& GA provided comments on the manuscript. All authors read and approved the final manuscript.

\section{Acknowledgements}

This research was supported by The University of the Philippines; The University of Santo Tomas; Royal Botanic Garden Edinburgh; Academia Sinica, Taiwan; National Science Council, Taiwan; the Royal Society of Edinburgh and the M.L. Maclntyre Begonia Trust. The authors are grateful to the curators of A, B, BM, E, HAST, K, L, P, PNH and SING for access to specimens.

\section{Author details}

'Department of Biology, College of Arts and Sciences, University of the Philippines Manila, Padre Faura, Manila 1000, Philippines. ${ }^{2}$ Royal Botanic Garden Edinburgh, 20a Inverleith Row, Edinburgh EH3 5LR, UK. ${ }^{3}$ College of Science and Research Centre for the Natural and Applied Sciences, University of Santo Tomas, España, Manila 1015, Philippines. ${ }^{4}$ Biodiversity Research Center, Academia Sinica, Taipei 115, Taiwan.

Received: 16 September 2013 Accepted: 16 September 2013 Published: 24 September 2013

\section{References}

Doorenbos J, Sosef MSM, de Wilde JJFE (1998) The sections of Begonia including descriptions, keys and species lists. Wageningen Agr. Univ. Pap. 98-2:1-266

Forrest LL, Hughes M, Hollingsworth PM (2005) A phylogeny of Begonia using nuclear ribosomal sequence data and morphological characters. Sys. Bot. 30:671-682

Hughes M (2008) An Annotated Checklist of Southeast Asian Begonia. Royal Botanic Garden, Edinburgh, UK, p 164

Hughes M, Girmansyah D (2011) Searching for Sumatran Begonia described by William Jack: following in the footsteps of a 19th century Scottish botanist. Gard. Bull. Sing. 63:83-96

Kiew R (2005) Begonias of Peninsular Malaysia. Natural History Publications, Borneo, Kota Kinabalu, p 308

Klotzsch JF (1855) Begoniaceen - Gattungen und Arten. Abh. Königl. Akad. Wiss, Berlin 1854:121-255

Ronquist F, Teslenko M, van der Mark P, Ayres D, Darling A, Höhna S, Larget B, Liu L, Suchard MA, Huelsenbeck JP (2012) MrBayes 3.2: Efficient Bayesian phylogenetic inference and model choice across a large model space. Syst Biol 61:1-4

Rubite RR (2012) Delimitation of Begonia L. sections Diploclinium and Baryandra (Begoniaceae) in the Philippines. Asia Life Sci 21:363-373

Shui YM, Peng C-I, Wu CY (2002) Synopsis of the Chinese species of Begonia (Begoniaceae), with a reappraisal of sectional delimitation. Bot. Bull. Acad. Sin. 43:313-327

Tebbitt MC, Forrest LL, Santoriello A, Clement W, Swensen SM (2006) Phylogenetic relationships of Asian Begonia, with an emphasis on the evolution of rain-ballist and animal dispersal mechanisms in sections Platycentrum, Sphenanthera and Leprosae. Syst. Bot. 31:327-336

Thomas DC, Hughes M, Phutthai T, Rajbhandary S, Rubite R, Ardi WH, Richardson JE (2011) A non-coding plastid DNA phylogeny of Asian Begonia (Begoniaceae): evidence for morphological homoplasy and sectional polyphyly. Mol Phylogenet Evol 60:428-444

\section{doi:10.1186/1999-3110-54-38}

Cite this article as: Rubite et al:: Recircumscription of Begonia sect. Baryandra (Begoniaceae): evidence from molecular data. Botanical Studies 2013 54:38

\section{Submit your manuscript to a SpringerOpen ${ }^{\circ}$ journal and benefit from:}

- Convenient online submission

- Rigorous peer review

- Immediate publication on acceptance

- Open access: articles freely available online

- High visibility within the field

- Retaining the copyright to your article

Submit your next manuscript at $\gg$ springeropen.com 